\title{
Analisis Hubungan Media Pembelajaran Berbasis Teknologi Informasi dengan Minat Belajar Siswa
}

\author{
Marini Nur Aina ${ }^{1)}$, Jenie Sundari ${ }^{2)}$ \\ ${ }^{12)}$ Jurusan Teknik Informatika, STMIK Nusa Mandiri Jakarta \\ Jl. Kramat Raya No. 18 Jakarta Pusat \\ Email:marininai@yahoo.com ${ }^{1)}$, Jenie.jni@nusamandiri.ac.id ${ }^{2)}$
}

\begin{abstract}
The sophistication of information technology now be utilized for various aspects, among them educational aspects. Where this technology is used for teachers and students. Which aims to provide other methods of learning, so that students are expected to be more interested in receiving learning materials. The purpose of this study is to analyze whether there is a relationship between the mediaof information technology-based learning with student interest by respondent teachers and students. This study is a research type of explanation, because this research is intended to explain the variables by testing the hypothesis that has been formulated previously. The study population was all teachers and students of class VI of the 75 teachers and 184 students, with the sample used by 43 teachers and 65 students. Data were analyzed using correlation analysis. The research proves the results of the partial test between the variables of Information Technology Based Learning Media $(X)$ with Student Interests $(Y)$ are as follows: partial results for the respondent teachers thitung of (0.020)> ttable (0.05) and the value probability equal to 0.353. The conclusion that media information technology-based learning is positively related to the weak student interest by respondent teachers, partial results thitung for student respondents was (0.020)> ttable (0.05) and a probability value of 0.288. The conclusion that media information technology-based learning is positively related to the weak interest in student learning based onstudent respondent.
\end{abstract}

Keywords : Media Information, Information Technology, Interest Learning.

\begin{abstract}
ABSTRAK
Kecanggihan teknologi informasi sekarang dapat dimanfaatkan untuk berbagai aspek, di antaranya aspek pendidikan. Dimana teknologi ini digunakan untuk guru dan siswa. Yang bertujuan untuk memberikan metode lain dalam belajar, sehingga diharapkan siswa lebih tertarik menerima materi belajar. Tujuan Penelitian ini adalah untuk menganalisis apakah terdapat hubungan antara media pembelajaran berbasis teknologi informasi dengan minat belajar siswa berdasarkan responden guru dan siswa. Penelitian ini merupakan tipe penelitian penjelasan, karena penelitian ini bermaksud menjelaskan variabel-variabel melalui pengujian hipotesis yang telah dirumuskan sebelumnya. Populasi penelitian ini adalah semua guru dan siswa kelas VI yang berjumlah 75 guru dan 184 siswa, dengan sampel yang digunakan sebanyak 43 guru dan 65 siswa. Data di analisa dengan menggunakan analisa korelasi. Hasil penelitian membuktikan hasil uji secara parsial antara variabel-variabel Media Pembelajaran Berbasis Teknologi Informasi $(X)$ dengan Minat Belajar Siswa $(Y)$ adalah sebagai berikut: secara parsial hasil thitung untuk responden guru sebesar $(0,035)<$ ttabel $(1,683)$ dan nilai probabilitas sebesar 0,322. Kesimpulannya bahwa media pembelajaran berbasis teknologi informasi mempunyai hubunganyang cukup dengan minat belajar siswa berdasarkan responden guru, secara parsial hasil thitung untuk responden siswa sebesar $(0,120)<$ ttabel $(1,6694)$ dan nilai probabilitas sebesar 0,195. Kesimpulannya bahwa media pembelajaran berbasis teknologi informasi mempunyai hubungan yang lemah dengan minat belajar siswa berdasarkan responden siswa.
\end{abstract}

Kata kunci : media pembelajaran, teknologi informasi, minat belajar 


\section{Pendahuluan}

Perkembangan teknologi informasi yang semakin pesat pada saat ini tidak bisa dihindari lagi pengaruhnya terhadap dunia pendidikan. Tuntutan global menuntut dunia pendidikan untuk selalu senantiasa menyesuaikan perkembangan teknologi informasi terhadap usaha dalam peningkatan mutu pendidikan, terutama penyesuaian penggunaan teknologi informasi bagi dunia pendidikan khususnya dalam proses pembelajaran.

Kecenderungan perubahan dan inovasi dalam dunia pendidikan akan terus terjadi dan berkembang dalam memasuki abad ke-21 sekarang ini. Perubahan tersebut antara lain: lebih mudah dalam mencari sumber belajar, lebih banyak pilihan untuk menggunakan dan memanfaatkan teknologi informasi, makin meningkatnya peran media dan multimedia dalam kegiatan pembelajaran, waktu belajar lebih fleksibel, penggunaan pembelajaran berbasis komputer, penggunaan media televisi/video dan lain-lain.

Melihat perkembangan saat ini maka bukan waktunya lagi guru untuk memberikan pengajaran secara konvensional (teacher center) dengan hanya menggunakan metode ceramah dan hafalan, hal ini diperkuat oleh pendapat Stine.

"Cara belajar sistem pendidikan kita yang diterapkan kepada kita sejak masa kanak-kanak, yaitu cara belajar kuno dan tidak produktif. Pendekatan model lama ini sebenarnya lebih menimbulkan keburukan dari pada kebaikan dan membuat proses belajar menjadi sulit bagi anak. Sejak dulu sistem sekolah mengajarkan kepada anak- anak untuk menghafalkan tanpa berpikir”. [1]

Dalam melakukan aktivitas belajar seorang siswa memerlukan adanya dorongan tertentu agar kegiatan belajarnya dapat menghasilkan prestasi belajar sesuai dengan tujuan yang diharapkan. Dorongan dalam belajar ini merupakan suatu hal yang sangat diperlukan bagi siswa untuk dapat berkembang dan mampu mencapai hasil belajar yang lebih baik yaitu minat belajar. Dalam belajar, faktor minat memegang peranan yang penting karena minat yang dimiliki siswa akan menentukan hasil yang dicapai dari kegiatan pembelajaran.

Dilihat dari dasar filosofi, pembelajaran pada hakikatnya adalah proses komunikasi yang bertujuan untuk penyampaian pesan/informasi sehingga dapat merangsang pikiran, perasaan dan minat serta perhatian siswa. Dalam proses pembelajaran, pengembangan materi/ bahan ajar dapat melalui berbagai cara, salah satunya adalah pengembangan bahan ajar dengan optimalisasi media. Media yang digunakan untuk memperlancar komunikasi dalam proses pembelajaran sering diistilahkan media pembelajaran.

Pemanfaatan teknologi pembelajaran berada pada kategori baik ditinjau dari segi indikator yaitu media hasil teknologi cetak, media hasil teknologi audio visual, media teknologi berbasis computer, media hasil teknologi gabungan. Motivasi belajar siswa berada pada kategori sangat tinggi ditinjau dari adanya keiinginn yang menarik dalam belajar, adanya dorongan dan kebutuhan dalam belajar, dan adanya lingkungan belajar yang kondusif. Berdasarkan analisis regresi linear sederhana pengaruh pemanfaatan teknologi pembelajaran terhadap motivasi belajar siswa SMPN 1 Lanrisang Kabupaten PinrangHasil analisa korelasi product momentdiperoleh sebesar 0,411 dengan tingkat hubungan sedang dan dapat dinyatakan ada hubungan pemanfaatan teknologi pembelajaran terhadap motivasi belajar siswa SMPN 1 Lanrisang Kabupaten Pinrang. [2]

Berdasarkan hasil penelitian dan pembahasan maka dapat diambil kesimpulan dalam penelitian ini, yaitu sebagai berikut: 1) Terdapat pengaruh yang signifikan variabel penggunaan gadget (X1) terhadap hasil belajar siswa kelas XI IIS di SMAN 1 Kepanjen; 2) Terdapat pengaruh yang signifikan antara variable minat belajar siswa (X2) terhadap hasil belajar siswa kelas XI IIS di SMAN 1 Kepanjen; 3) Terdapat pengaruh yang signifikan variabel kecerdasan emosional (X3) terhadap hasil belajar siswa kelas XI IIS di SMAN 1 Kepanjen; 4) Terdapatpenaruh yang signifikan variabel penggunaan gadget (X1), minat belajar (X2), dankecerdasan emosional (X3) terhadap hasil belajar siswa kelas XI IIS di SMAN 1Kepanjen. [3]

\section{A. Metode Penelitian}

1. Definisi Media

a. Pembelajaran Berbasis Teknologi Informasi

Pemakaian media pembelajaran dalam proses belajar mengajar dapat membangkitkan keinginan dan minat yang baru, membangkitkan motivasi dan rangsangan kegiatan belajar, dan bahkan membawa pengaruhpengaruh psikologis terhadap siswa. [4]

Media pembelajaran, menurut Kemp \& Dayton (1985:28), dapat memenuhi tiga fungsi utama apabila media itu digunakan untuk perorangan, kelompok, atau kelompok pendengar yang besar jumlahnya, yaitu: (1) memotivasi minat atau tindakan, (2) menyajikan informasi, dan (3) memberi instruksi. [5]

2. Definisi Minat Belajar

Minat adalah kecenderungan yang tetap untuk memperhatikan dan mengenang beberapa kegiatan. Kegiatan yang diminati seseorang, diperhatikan terus menerus disertai dengan rasa senang.[6]

Minat berarti kecenderungan dan kegairahan yang tinggi atau keinginan yang besar terhadap sesuatu.[7]

Minat merupakan suatu kekuatan (power) atau tenaga (forces) atau daya (energy) atau suatukeadaan yang kompleks dan kesiapsediaan (preparatory set) dalam diri individu untuk bergerak kearah tujuan tertentu, baik disadari maupun tidak disadari. Minat mengarahkan perbuatan kepadasuatu tujuan dan merupakan dorongan bagi perbuatan tersebut. Dalam diri manusia terdapatdorongan-dorongan (motif- motif) yang mendorong manusia untuk berinteraksi dengan dunia luar,motif menggunakan dan menyelidiki dunia luar (manipulate and exploring motives). Dari manipulasi dan eksplorasi yang dilakukan terhadap dunia luar itu, lama-kelamaan timbullah minat terhadap sesuatu tersebut. Apa yang menarik minat 
seseorang mendorongnya untuk berbuat lebih giat dan lebih baik [8]. [9]:

Metode pengumpulan data yang digunakan adalah

a. Observasi

Didalam artinya penelitian observasi adalah mengadakan pengamatan secara langsung, observasi dapat melakukan dengan wawancara, kuesioner. Pedoman observasi berisi sebuah daftar jenis kegiatan yang mungkin timbul dan akan diamati.

b. Wawancara

Wawancara digunakan oleh peneliti untuk menilai keadaan seseorang, misalnya sebagai pendukung untuk mendapatkan keterangan tambahan dari responden dan dari pihak sekolah.

c. Angket atau Kuesioner Kuesioner adalah sejumlah pertanyaan tertulis yang digunakan untuk memperoleh informasi dari responden dalam arti laporan tentang pribadinya, atau hal-hal yang diketahui.

d. Skala bertingkat

Skala bertingkat adalah suatu ukuran subyektif yang dibuat berskala. Walaupun skala bertingkat ini menghasilkan data yang kasar, tetapi cukup memberikan informasi tertentu tentang program atau orang. Instrumen ini dapat dengan mudah memberikan gambaran penampilan, terutama penampilan di dalam orang yang menjalankan tugas, yang menunjukan frekuensi munculnya sifat-sifat. Di dalam menyusun skala, yang perlu diperhatikan adalah bagaimana menentukan variabel skala. Apa yang ditanyakan harus apa yang diamati responden.[10]

Dari beberapa jenis skala, ternyata skala interval yang sering digunakan untuk mengukur gejala dalam penelitian sosial. Bentuk skala sikap yang digunakan dalam penelitian ini adalah skala Likert. Dengan skala Likert, maka variabel yang akan diukur dijabarkan menjadi dimensi, dimensi dijabarkan lagi menjadi indikator-indikator yang dapat diukur. Teknik pengambilan data dilakukan dengan cara observasi langsung, dan penyebaran kuesioner untuk mendapatkan data primer, sedangkan untuk data sekunder berasal dari studi pustaka. Dalam penelitian ini peneliti menggunakan teknik pengambilan sampel dengan Purposive Sampling. Dimana pengambilan sample ini dengan pertimbangan tertentu. Penentuan jumlah sampel pada penelitian ini menggunakan rumus sebagai berikut

$\mathrm{n}=$

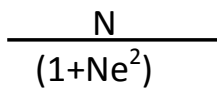

Keterangan :

$\mathrm{N}=$ Perkiraan jumlah sample

$\mathrm{N}=$ Besar Populasi

$\mathrm{E}=$ Presentasi kelonggaran ketidak telitian karena kesalahan sampel yang masih bias ditolelir $10 \%$.

\section{Hasil dan Pembahasan}

A. Karakteristik Responden Guru
Tabel.1 Data Responden Menurut Usia

\begin{tabular}{|c|c|c|}
\hline Usia & Jumlah & Persentase \\
\hline $21-30$ & 6 & 13,96 \\
\hline $31-40$ & 13 & 30,23 \\
\hline $41-50$ & 9 & 20,93 \\
\hline $51-60$ & 15 & 34,88 \\
\hline Total & 43 & 100 \\
\hline
\end{tabular}

Berdasarkan pada Tabel IV.1, diketahui bahwa responden terbanyak pada penelitian ini yaitu berusia 51-60 tahun dengan persentase 34,88\%

Tabel 2. Data Responden Menurut Pendidikan Terakhir

\begin{tabular}{|l|c|c|}
\hline $\begin{array}{c}\text { Pendidikan } \\
\text { Terakhir }\end{array}$ & Jumlah & Persentase \\
\hline SLTA & 0 & 0 \\
\hline Diploma & 1 & 2,32 \\
\hline Sarjana & 40 & 93,03 \\
\hline Magister & 2 & 4,65 \\
\hline \multicolumn{1}{|c|}{ Total } & 43 & 100 \\
\hline
\end{tabular}

Berdasarkan pada Tabel IV.2, diketahui bahwa guru dengan pendidikan terakhir SLTA sebesar 0\%, guru dengan pendidikan terakhir diploma sebesar $2,32 \%$, guru dengan pendidikan terakhir sarjana sebesar 93,03\%, dan guru dengan pendidikan terakhir magister sebesar $4,65 \%$.

Tabel 3. Data Responden Menurut Status Kepegawaian

\begin{tabular}{|l|c|c|}
\hline $\begin{array}{c}\text { Status } \\
\text { Kepegawaian }\end{array}$ & Jumlah & Persentase \\
\hline Tetap & 32 & 74,42 \\
\hline Tidak Tetap & 11 & 25,58 \\
\hline Total & 43 & 100 \\
\hline
\end{tabular}

Berdasarkan pada Tabel IV.3, diketahui bahwa mayoritas guru pada penelitian ini adalah dengan status kepegawaian tetap sebesar $74,42 \%$, dan guru dengan status kepegawaian tidak tetap sebesar $25,58 \%$.

\section{B. Karakteristik Responden Siswa}

Tabel 4. Data Responden Menurut Jenis Kelamin

\begin{tabular}{|l|c|c|}
\hline \multicolumn{1}{|c|}{ Jenis Kelamin } & Jumlah & Persentase \\
\hline Perempuan & 40 & 61,54 \\
\hline Laki-laki & 25 & 38,46 \\
\hline Total Responden & 65 & 100 \\
\hline
\end{tabular}

Berdasarkan pada Tabel IV.4, diketahui bahwa siswa dengan jenis kelamin perempuan lebih banyak dari pada jenis kelamin laki-laki dengan persentase jenis kelamin perempuan sebesar $61,54 \%$ dan jenis kelamin laki-laki sebesar $38,46 \%$.

Tabel 5. Data Responden Menurut Usia

\begin{tabular}{|c|c|c|}
\hline Usia & Jumlah & Persentase \\
\hline 12 Tahun & 16 & 24,62 \\
\hline 13 Tahun & 49 & 75,38 \\
\hline Total & 65 & 100 \\
\hline
\end{tabular}


Berdasarkan pada Tabel IV.5, diketahui bahwa mayoritas responden dalam penelitian ini adalah siswa dengan usia 13 tahun sebesar 75,38\%, sedangkan siswa dengan usia 12 tahun sebesar $25,62 \%$.

\section{Analisa Deskriptif}

Berdasarkan data yang diolah dapat diketahui bahwa bahwa rata-rata keseluruhan responden guru untuk variabel media pembelajaran berbasis teknologi informasi adalah 145,125 dan termasuk kategori rendah. Artinya menurut responden guru pada penelitian ini media pembelajaran berbasis teknologi informasi di beberapa SDN Sumur Batu mempunyai hubungan yang rendah.

Berdasarkan data yang diolah dapat diketahui bahwa rata-rata keseluruhan responden siswa untuk variabel media pembelajaran berbasis teknologi informasi adalah 210.375 dan termasuk kategori rendah.

Artinya menurut responden siswa pada penelitian ini media pembelajaran berbasis teknologi informasi di beberapa SDN Sumur Batu mempunyai hubungan yang rendah.

Berdasarkan data yang diolah dapat diketahui bahwa rata-rata keseluruhan responden guru untuk variabel minat belajar siswa adalah 188,625 dan termasuk kategori tinggi. Artinya menurut responden guru pada penelitian ini minat belajar siswa di beberapa SDN Sumur Batu mempunyai hubungan yang signifikan.

Berdasarkan data yang diolah dapat diketahui bahwa rata-rata keseluruhan responden siswa untuk variabel media pembelajaran berbasis teknologi informasi adalah 261,125 dan termasuk kategori tinggi. Artinya menurut responden siswa pada penelitian ini minat belajar siswa di beberapa SDN Sumur Batu mempunyai hubungan yang signifikan.

\section{Uji Validitas}

Berdasarkan hasil uji validitas dari data yang diolah dapat dilihat bila koefisien korelasi untuk responden guru sama dengan 0,3008 atau lebih, maka item dinyatakan valid. Sebaliknya, bila korelasi untuk responden guru lebih kecil dari 0.3008, maka item dinyatakan tidak valid. Terdapat 16 item pada variabel media pembelajaran berbasis teknologi informasi dengan variabel minat belajar siswa dan semua item tersebut dengan nilai lebih dari 0,3008 sehingga semua item dinyatakan valid.

Berdasarkan hasil uji validitas dari data yang diolah dapat dilihat bila koefisien korelasi untuk responden siswa sama dengan 0,2441 atau lebih, maka item dinyatakan valid. Sebaliknya, bila korelasi untuk responden siswa lebih kecil dari 0.2441, maka item dinyatakan tidak valid. Terdapat 16 item pada variabel media pembelajaran berbasis teknologi informasi dengan variabel minat belajar siswa dan semua item tersebut dengan nilai lebih dari 0,2441 sehingga semua item dinyatakan valid.

\section{E. Uji Reliabilitas}

Tabel 6. Hasil Pengujian Reliabilitas Pada Responden Guru

Reliability Statistics

$$
\begin{array}{|l|l|}
\text { Cronbach's Alpha } & \text { N of Items } \\
912 & 16
\end{array} \mid
$$

Sebagaimana diperlihatkan pada Tabel IV.14 di atas, hasil uji reliabilitas dapat dilihat dari nilai *.Correlation is significant at the 0.05 level (2-tailed).

Cronbach Alpha sebesar 0,912. Artinya, item responden guru dinyatakan reliabel karena nilai $\mathrm{r}=0,912$ $>$ rtabel $=0,3008$, maka item dapat digunakan untuk mengukur dalam rangka pengumpulan data Analisa Hubungan Media Pembelajaran Berbasis Teknologi Informasi Dengan Minat Belajar Siswa.

Tabel 7. Hasil Pengujian Reliabilitas Pada Responden Siswa

Reliability Statistics

$$
\begin{array}{|l|l|}
\text { Cronbach's Alpha } & \begin{array}{l}
\text { N of Items } \\
16
\end{array}
\end{array} \mid
$$

Sebagaimana diperlihatkan pada Tabel IV.15 di atas, hasil uji reliabilitas dapat dilihat dari nilai Cronbach Alpha sebesar 0,846. Artinya, item responden siswa dinyatakan reliabel karena nilai $\mathrm{r}=0,870>$ rtabel $=$ ,2441, maka item dapat digunakan untuk mengukur dalam rangka pengumpulan data Analisa Hubungan Media Pembelajaran Berbasis Teknologi Informasi Dengan Minat Belajar Siswa.

\section{F. Uji Korelasi}

Tabel 8. Hasil Pengujian Korelasi Pada

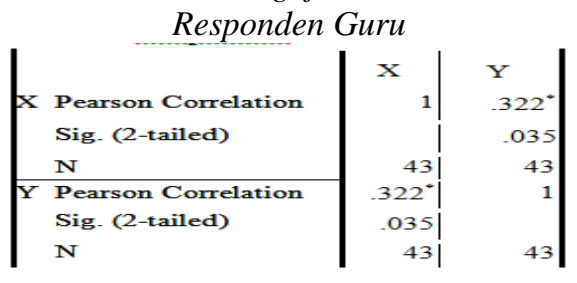

Berdasarkan Tabel IV.16, diketahui bahwa persamaan refrensi yang terbentuk adalah:

$$
\begin{aligned}
& =\frac{1771643-1753920 \mathrm{r}_{\mathrm{xy}}}{\sqrt{82946 \times 36544}} \\
& r_{x y}=\frac{17723}{\sqrt{3031178624}} \\
& r_{\mathrm{XX}}=0.32190778
\end{aligned}
$$

Artinya:

X (Media Pembelajaran Berbasis Teknologi Informasi) mempunyai hubungan yang cukup dengan Y (Minat 
Belajar Siswa) berdasarkan responden guru karena --1 < rxy $=0,322>+1$.

Tabel 9. Hasil Pengujian Korelasi Pada

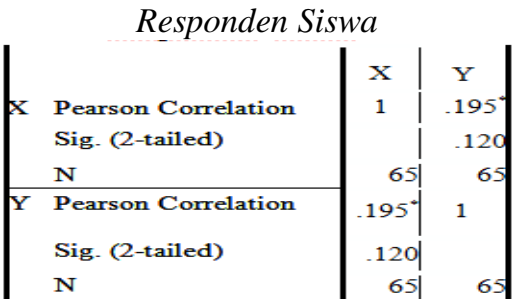

*. Correlation is significant at the 0.05 level (2-tailed). X (Media Pembelajaran Berbasis Teknologi Informasi) mempunyai hubungan yang lemah dengan $\mathrm{Y}$ (Minat Belajar Siswa) berdasarkan responden siswa karena $-1<$ rxy $=0,288>+1$.

\section{G. Uji T}

Pembelajaran berbasis teknologi informasi dengan minat belajar siswa berdasarkan responden guru. Berdasarkan analisa statistic dengan menggunakan taraf signifikan $\mathrm{t}_{\text {tabel }}=1,683$ dapat diketahui bahwa nilai $t_{\text {hitung }}=0,035<t_{\text {tabel }}=1,683$ dengan probabilitas 0,322 .

Maka variabel media pembelajaran berbasis teknologi informasi mempunyai nilai signifikan dan mempunyai hubungan yang cukup dengan minat belajar siswa berdasarkan responden guru di beberapa SDN Sumur Batu. Berarti H0 ditolak dan H1 diterima yaitu adanya hubungan media pembelajaran berbasis teknologi informasi dengan minat belajar siswa berdasarkan responden guru.

\section{H. Uji Hipotesis media Pembelajaran Berbasis Teknologi}

Berdasarkan Tabel IV.16, diketahui bahwa persamaan refrensi yang terbentuk adalah:

$$
\begin{aligned}
& r_{x y}=\frac{3546400-3515787}{\sqrt{261446 \times 94624}} \\
& r_{x y}= \\
& r_{x y}=\frac{\sqrt{ } 24739613}{30613} \\
& r_{x y}=
\end{aligned}
$$

Artinya :

informasi dengan minat belajar siswa berdasarkan responden siswa. Berdasarkan analisa statistik dengan menggunakan taraf signifikan ttabel $=1,6694$ dapat diketahui bahwa nilai $\mathrm{t}_{\text {hitung }}=0,120<\mathrm{t}_{\text {tabel }}=1,6694$ dengan probabilitas 0,195. Maka variable media pembelajaran berbasis teknologi informasi mempunyai nilai signifikan dan mempunyai hubungan yang lemah dengan minat belajar siswa berdasarkan responden siswa di beberapa SDN Sumur Batu. Berarti H0 ditolak dan H1 diterima yaitu adanya hubungan media pembelajaran berbasis teknologi informasi dengan minat belajar siswa berdasarkan responden siswa.

\section{Kesimpulan}

1. Media pembelajaran berbasis teknologi informasi dengan minat belajar siswa berdasarkan responden guru adalah cukup. Hal ini ditunjukan dari hasil thitung untuk responden guru sebesar $(0,035)<$ ttabel $(1,683)$ dan nilai probabilitas sebesar 0,322 dengan menggunakan kriteria korelasi diperoleh $1<$ rxy>+1. Kesimpulannya bahwa media pembelajaran berbasis teknologi informasi mempunyai hubungan yang cukup dengan minat belajar siswa berdasarkan responden guru.

2. Adanya hubungan media pembelajaran berbasis teknologi informasi dengan minat belajar siswa berdasarkan responden siswa adalah lemah. Hal ini ditunjukan dari hasil thitung untuk responden siswa sebesar $(0,120)>$ ttabel $(1,6694)$ dan nilai probabilitas sebesar 0,195 dengan menggunakan kriteria korelasi diperoleh $-1<$ rxy $>+1$. Kesimpulannya bahwa media pembelajaran berbasis teknologi informasi mempunyai hubungan yang lemah dengan minat belajar siswa berdasarkan responden siswa.

\section{Daftar Pustaka}

Rusman, Deni Kurniawan, dan Cepi Riyana. 2013. Pembelajaran Berbasis Teknologi Informasi dan Komunikasi Mengembangkan Profesionalitas Guru. Jakarta. PT Rajawali Pers.

Zabir Azhari, Pengaruh Pemanfaatan Teknologi Pembelajaran Terhadap Motivasi Belajar Siswa SMPN 1 Lanrisang Kabupaten Pinrang. 2018.

Sukarno Zulfikar Adilla, Prih Hardinto. Pengaruh Penggunaan Gadget, minat belajar dan kecerdasan emosional terhadap hasil belajar siswa kelas XI IIS pada mata pelajaran ekonomi di SMAN 1 Kepanjen.

Hamalik, Oemar. 1990. Metode Belajar dan KesulitanKesulitan Belajar. Bandung. Tarsito Asmani, Jamal. 2014. Tips Membangun Komunitas Belajar di Sekolah. Jogjakarta. DIVA Press.

Arsyad, Azhar. 2015. Media Pembelajaran. Jakarta. Rajawali Pers.

Slameto. Belajar dan faktor-faktor yang mempengaruhinya. Jakarta. Rineka Cipta. 1995.

Muhibbin Syah, Psikologi Belajar, (Jakarta: PT Raja Grafindo Persada, 2009), hal. 65.

Ngalim Purwanto. 2007. Psikologi Pendidikan. Bandung: PT. Remaja Rosdakarya.

Sugiono. 2005. Metode Penelitian Administrasi. Alpabeta. Bandung.

Arikunto, Suharsimi. 2006. Prosedur Penelitian. Jakarta. Rineka Cipta. 